\title{
ANALISIS FAKTOR YANG MEMPENGARUHI CAKUPAN PENIMBANGAN BALITA KE POSYANDU DI KOTA PADANG TAHUN
} 2018

\author{
Meyi Yanti ${ }^{1}$, Nursal Asbiran ${ }^{2}$, Sukarsi Rusti ${ }^{3}$ \\ Program Studi Magister Kesehatan Masyarakat, STIKes Fort De Kock Bukittinggi \\ Jl. Soekarno Hatta Kota Bukittinggi, Sumatera Barat. 26117 \\ email:meyyanti11@yahoo.com \\ nursal.asbiran@gmail.com \\ rustiuci@gmail.com
}

\begin{abstract}
Abstrak
Cakupan anak ditimbang persasaran (D/S) di Posyandu merupakan indikator tinggi/rendahnya partisipasi masyarakat. Berdasarkan profil Dinas Kesehatan Kota Padang tahun 2017 cakupan penimbangan balita sebesar $71,10 \%$, hasil ini masih dibawah target pemerintah yaitu $85 \%$ (Padang, 2017). Tujuan Penelitian menganalisis faktor yang mempengaruhi cakupan penimbangan balita ke Posyandu Balita di Kota Padang tahun 2018. Jenis penelitian ini adalah Mix Methods, penelitian ini dilakukan di Kota Padang, data dikumpulkan mulai tanggal 24 September s/d 8 Desember 2018. Populasi dalam penelitian ini adalah ibu yang memiliki balita sebanyak 63.644 dengan jumlah sampel ibu yang memiliki balita $12 \mathrm{~s} / \mathrm{d} 59$ bulan yaitu $381 \mathrm{ibu}$. Analisis data yang dengan univariat, bivariat dan multivariat. Sedangkan kualitatif dengan menggunakan triangulasi data. Hasil penelitian menunjukkan ada hubungan tingkat pendidikan, pekerjaan, tingkat pengetahuan, motivasi ibu, dukungan keluarga dan dukungan tokoh masyarakat dengan cakupan penimbangan balita(D/S) ke Posyandu balita. Hasil analisis statistik faktor paling berpengaruh terhadap cakupan penimbangan balita adalah dukungan keluarga. Kebijakan terkait program posyandu sudah ada di Kota Padang, hasil cakupan penimbangan balita masih dibawah target pemerintah $85 \%$.
\end{abstract}

Kata Kunci: Faktor yang mempengaruhi cakupan penimbangan balita

\section{ANALYSIS OF FACTORS THAT INFLUENCE THE COVERAGE OF UNDER-FIVES CONSIDERATION TO POSYANDU IN PADANG CITY IN 2018}

\begin{abstract}
The coverage of children weighed in the target (D / S) in Posyandu is an indicator of high/low community participation. Based on the profile of the Padang City Health Office in 2017 the coverage of under five weighings was $71.10 \%$, this result was still below the government's target of $85 \%$. From the weighing, BGM infants were found to be $2.81 \%$. Research Objectives To analyze the factors that influence the coverage of under-fives weighing in under-fives Posyandu in Padang City in 2018. This type of research is Mix Methods (Quantitative and Qualitative Combined); this research was conducted in Padang City; data were collected from September 24 to December 8, 2018. The population in this study were 63,444 mothers with toddlers with a sample of mothers who had toddlers 12 to 59 months, namely 381 mothers. For quantitative data analysis with univariate, bivariate and multivariate. While qualitative using data triangulation. The results showed that there was a correlation between education level, occupation, level of knowledge, mother's motivation, family support and support from community leaders with coverage of under five weighing $(D / S)$ to toddlers Posyandu. From the results of statistical analysis the factors that most influence the coverage of under five weighings are family support. Policies related to the posyandu program already exist in the city of Padang, the results of the coverage of weighing under-fives are still below the government's target of $85 \%$.
\end{abstract}

Keywords: factors that influence the coverage of under five weighing 


\section{PENDAHULUAN}

Cakupan anak ditimbang persasaran (D/S) di Posyandu merupakan indikator tinggi/rendahnya partisipasi masyarakat. Berdasarkan profil Dinas Kesehatan Kota Padang tahun 2017 cakupan penimbangan balita sebesar $71,10 \%$, hasil ini masih dibawah target pemerintah yaitu $85 \%$. Dari penimbangan tersebut balita BGM ditemukan sebesar $2,81 \%$.

Indikator yang digunakan dalam pengukuran pelaksanaan posyandu ini antara lain frekuensi kunjungan (penimbangan) setiap bulan, namun tidak semua posyandu dapat berfungsi setiap bulan sehingga frekuensinya kurang dari 12 kali setahun. Menurut (Zulkifli, 2003) posyandu dikatakan aktif, apabila frekuensi penimbangan di atas 8 kali setahun.

Menurut Lawrence Green (1980) dalam (Soekidjo Notoadmodjo, 2012), perilaku seseorang dipengaruhi oleh 3 faktor utama yaitu faktor-faktor predisposisi, faktorfaktor pemungkin, dan faktor-faktor penguat.

Predisposisi mencakup pengetahuan dan sikap masyarakat terhadap kesehatan, tradisi dan kepercayaan masyarakat terhadap hal-hal yang berkaitan dengan kesehatan, sistem nilai yang dianut masyarakat, tingkat pendidikan, tingkat sosial ekonomi dan sebagainya (Soekidjo Notoadmodjo, 2012). Perilaku ibu mengunjungi posyandu membawa anak balitanya, akan dipermudah jika ibu tahu apa manfaat membawa anak ke posyandu.

Karakteristik ibu yang merupakan bagian dari karakteristik individu seseorang mempunyai peranan penting terhadap pertumbuhan balita. Dari hasil penelitian (A.H Angkat, 2015) menyatakan bahwa partisipasi ibu ke posyandu di Desa Penanggalan Kecamatan Penanggalan Kota Subulussalam Tahun 2015 selama 1 tahun masih rendah tetapi partisipasinya sudah baik. Faktor yang berhubungan dengan partisipasi ibu ke posyandu adalah pengetahuan ibu, sikap ibu, jarak, dukungan dari petugas kesehatan. Hal ini sesuai dengan beberapa pernyataan dan pendapat para peneliti. Faktor-faktor yang mempengaruhi partisipasi ibu ke Posyandu Balita adalah sebagai berikut: Pendidikan Ibu, Pekerjaan Ibu, Tingkat Pengetahuan Ibu, Jarak ke Posyandu, Motivasi Ibu, Dukungan Keluarga dan Tokoh Masyarakat.

\section{METODE PENELITIAN}

Jenis penelitian ini adalah Mix Methods (Gabungan Kuantitaif dan Kualitatif), penelitian ini dilakukan di Kota Padang, data dikumpulkan mulai tanggal 24 September s/d 8 Desember 2018. Populasi dalam penelitian ini adalah ibu yang memiliki balita dengan jumlah sampel ibu yang memiliki balita $12 \mathrm{~s} / \mathrm{d}$ 59 bulan yaitu 381 ibu. Untuk kuantitatif analisis data yang dengan univariat menggunakan distribusi frekuensi, bivariat menggunakan uji statistik Chi-Square dan multivariat menggunakan uji Regresi Logistik. Sedangkan kualitatif dengan menggunakan triangulasi data.

\section{HASIL DAN PEMBAHASAN}

1. Analisis Univariat

Tabel 1. Distribusi Frekuensi berdasarkan Analisis Univariat

\begin{tabular}{|c|c|c|}
\hline Variabel & Frekuensi & Persentase \\
\hline \multicolumn{3}{|c|}{ Cakupan Penimbangan Balita (D/S) } \\
\hline Rendah & 186 & 48,8 \\
\hline Tinggi & 195 & 51,2 \\
\hline \multicolumn{3}{|c|}{ Tingkat Pendidikan Ibu } \\
\hline Rendah & 235 & 61,7 \\
\hline Tinggi & 146 & 38,3 \\
\hline \multicolumn{3}{|l|}{ Pekerjaan Ibu } \\
\hline Bekerja & 160 & 42 \\
\hline Tidak Bekerja & 221 & 58 \\
\hline \multicolumn{3}{|c|}{ Tingkat Pengetahuan Ibu } \\
\hline Rendah & 116 & 30,4 \\
\hline Tinggi & 265 & 69,6 \\
\hline \multicolumn{3}{|c|}{ Jarak ke Posyandu Balita } \\
\hline Jauh & 12 & 3,1 \\
\hline Dekat & 369 & 96,9 \\
\hline \multicolumn{3}{|l|}{ Motivasi Ibu } \\
\hline Rendah & 157 & 41,2 \\
\hline Tinggi & 224 & 58,8 \\
\hline \multicolumn{3}{|c|}{ Dukungan Keluarga } \\
\hline Kurang Baik & 124 & 32,5 \\
\hline Baik & 257 & 67,5 \\
\hline \multicolumn{3}{|c|}{ Dukungan Tokoh Masyarakat } \\
\hline Kurang Baik & 193 & 50,7 \\
\hline Baik & 188 & 49,3 \\
\hline
\end{tabular}

responden $186(48,8 \%)$ cakupan penimbangan balita rendah, $235(61,7 \%)$ tingkat pendidikan ibu rendah, 160 (42\%) Ibu bekerja, 116 $(30,4 \%)$ tingkat pengetahuan ibu rendah, 12 (3,1\%) jarak ke Posyandu Balita jauh, 157 $(41,2 \%)$ motivasi ibu rendah, 124 (32,5\%) dukungan keluarga kurang baik dan 193 $(50,7 \%)$ dukungan tokoh masyarakat kurang baik. 
Berdasarkan (Kesehatan Kementerian, 2012) Menyebutkan bahwa dalam kegiatan Posyandu, tingkat partisipasi masyarakat disuatu wilayah diukur dengan melihat perbandingan antara jumlah anak balita di daerah kerja Posyandu (S) dengan jumlah balita ditimbang pada setiap kegiatan Posyandu yang ditentukan (D). Angka D/S menggambarkan kecakupan anak balita yang ditimbang, ini merupakan indikator tingkat partisipasi masyarakat untuk menimbangkan anak balitanya. Hasil cakupan penimbangan balita merupakan salah satu alat untuk memantau gizi balita yang dapat dimonitor dari berat badan hasil penimbangan yang tercatat di dalam KMS. Berdasarkan asumsi peneliti, bahwa cakupan penimbangan balita $(\mathrm{D} / \mathrm{S})$ masih rendah kemungkinan ada

2. Analisis Bivariat

Tabel 2. Analisis Bivariat

\begin{tabular}{|c|c|c|c|c|c|c|c|c|}
\hline \multirow[t]{3}{*}{ Variabel } & \multicolumn{4}{|c|}{ Cakupan Penimbangan Balita (D/S) } & \multirow{2}{*}{\multicolumn{2}{|c|}{ Jumlah }} & \multirow{3}{*}{ P Value } & \multirow{3}{*}{ OR (CI 95\%) } \\
\hline & \multicolumn{2}{|c|}{ Rendah } & \multicolumn{2}{|c|}{ Tinggi } & & & & \\
\hline & $\mathbf{N}$ & $\%$ & $\mathbf{N}$ & $\%$ & $\mathbf{n}$ & $\%$ & & \\
\hline \multicolumn{9}{|l|}{ Pendidikan } \\
\hline Rendah & 125 & 53,2 & 110 & 46,8 & 235 & 100 & \multirow[b]{2}{*}{0,039} & \multirow[b]{2}{*}{1,583} \\
\hline Tinggi & 61 & 41,8 & 85 & 58,2 & 146 & 100 & & \\
\hline \multicolumn{9}{|l|}{ Pekerjaan } \\
\hline Bekerja & 90 & 56,3 & 70 & 43,8 & 160 & 100 & \multirow{2}{*}{0,018} & \multirow{2}{*}{1,674} \\
\hline Tidak Bekerja & 96 & 43,4 & 125 & 56,6 & 221 & 100 & & \\
\hline \multicolumn{9}{|c|}{ Tingkat Pengetahuan } \\
\hline Rendah & 69 & 59,5 & 47 & 40,5 & 116 & 100 & \multirow{2}{*}{0,008} & \multirow{2}{*}{1,857} \\
\hline Tinggi & 117 & 44,2 & 148 & 55,8 & 265 & 100 & & \\
\hline \multicolumn{9}{|c|}{ Jarak Posyandu } \\
\hline Jauh & 7 & 58,3 & 5 & 41,7 & 12 & 100 & \multirow{2}{*}{0,706} & \multirow{2}{*}{1,486} \\
\hline Dekat & 179 & 48,5 & 190 & 51,5 & 369 & 100 & & \\
\hline \multicolumn{9}{|l|}{ Motivasi } \\
\hline Rendah & 87 & 55,4 & 70 & 44,6 & 157 & 100 & \multirow{2}{*}{0,040} & \multirow{2}{*}{1,569} \\
\hline Tinggi & 99 & 44,2 & 125 & 55,8 & 224 & 100 & & \\
\hline \multicolumn{9}{|c|}{ Dukungan Keluarga } \\
\hline Kurang Baik & 77 & 62,1 & 47 & 37,9 & 124 & 100 & \multirow{2}{*}{0,0001} & \multirow{2}{*}{2,224} \\
\hline Baik & 109 & 42,4 & 148 & 57,6 & 257 & 100 & & \\
\hline \multicolumn{9}{|c|}{ Dukungan Tokoh Masyarakat } \\
\hline Kurang Baik & 106 & 54,9 & 87 & 45,1 & 193 & 100 & \multirow{2}{*}{0,021} & \multirow{2}{*}{1,645} \\
\hline Baik & 80 & 42,6 & 108 & 57,4 & 188 & 100 & & \\
\hline
\end{tabular}

beberapa faktor yang mempengaruhi seperti tingkat pendidikan ibu, pekerjaan ibu, tingkat pengetahuan ibu tentang Posyandu, Motivasi Ibu, dukungan yang diberikan oleh keluarga dan

dukungan yang diberikan oleh tokoh masyarak at.Dan perlu adanya keterlibatan pemerintah daerah dalam kegiatan Posyandu Balita, dan antara pemerintah daerah dalam hal ini adalah Kecamatan, Kelurahan, RT/RW dan Tokoh Masyarakat saling berinteraksi dengan Dinas Kesehatan Kota Padang dalam kegiatan Posyandu ini. Dan masyarakat harus menyadari bahwa Posyandu merupakan kegiatan Upaya Kegiatan Berbasis Masyarakat (UKBM) yang berarti kegiatan tersebut dari,untuk dan oleh masyarakat itu sendiri. 
Berdasarkan tabel diatas terdapat hubungan yang bermakna antara tingkat pendidikan dengan cakupan penimbangan balita di Posyandu Kota Padang tahun 2018 dengan nilai OR 1,583. terdapat hubungan yang bermakna antara pekerjaa dengan cakupan penimbangan balita di Posyandu Kota Padang tahun 2018 dengan nilai OR 1,674. Terdapat hubungan yang bermakna antara tingkat pengetahuan dengan cakupan penimbangan balita di Posyandu Kota Padang tahun 2018 dengan nilai OR 1,857. Terdapat hubungan yang bermakna antara motivasi dengan cakupan penimbangan balita di Posyandu Kota Padang tahun 2018 dengan nilai OR 1,569. Terdapat hubungan yang bermakna antara dukugan keluarga dengan cakupan penimbangan balita di Posyandu Kota Padang tahun 2018 dengan nilai OR 2,224. Terdapat hubungan yang bermakna antara dukungan tokoh masyarakat dengan cakupan penimbangan balita di Posyandu Kota Padang tahun 2018 dengan nilai OR 1,645.

Hasil penelitian ini sama dengan penelitian yang dilakukan oleh (Ann, 2017) di Kitui County Kenya bahwa ada hubungan pendidikan ibu dengan partisipasi ibu ke pelayanan kesehatan dan menyatakan faktor pendidikan ibu balita yang baik akan mendorong ibu-ibu balita untuk membawa anaknya ke pelayanan kesehatan. Hasil penelitian ini juga sejalan dengan penelitian yang dilakukan oleh (Jane Ilusa Nyabuti, 2015) di Nyamira didapatkan hasil bahwa ada hubungan tingkat pendidikan dengan pemantauan pertumbuhan pada anak usia 10-59 bulan dengan $p$ value $=0$, 003.

Berdasarkan asumsi peneliti, pendidikan merupakan salah satu faktor yang penting dalam tumbuh kembang anak, karena dengan pendidikan yang baik, maka orang tua dapat menerima segala informasi dari luar terutama tentang cara pengasuhan anak yang baik, bagaimana menjaga kesehatan anaknya, pendidikannya dan sebagainya dan ibu yang memiliki tingkat pendidikan tinggi cenderung akan membawa anaknya ke Posyandu Balita. Pada dasarnya perilaku ibu membawa balita ke Posyandu pada ibu yang bekerja dan tidak bekerja dan tidak bekerja seharusnya tidak memiliki perbedaan, dikarenakan perilaku tersebut didasari oleh seberapa besar pengetahuan $\mathrm{ibu}$ tentang Posyandu dan bagaimana mensikapinya. Namun rendahnya cakupan penimbangan balita ke Posyandu menunjukkan bahwa ada pengaruh dari faktor status ibu bekerja atau tidaknya. Berdasarkan hasil penelitian dan teori diatas dapat disimpulkan bahwa ibu balita yang memiliki cakupan penimbangan balita $(\mathrm{D} / \mathrm{S})$ rendah lebih banyak pada ibu yang bekerja dibandingkan dengan ibu yang tidak bekerja. Namun tidak menutup kemungkinan bahwa ibu yang bekerja mempunyai peluang untuk berpartisipasi aktif dalam kegiatan posyandu. Berdasarkan hasil kuesioner ditemukan bahwa dari $56,3 \%$ ibu yang bekerja, 30\% memiliki cakupan penimbangan balita (D/S) tinggi, hal ini disebabkan oleh ada anggota keluarga lain yang membantu membawa balita ke Posyandu. Hasil ini juga didukung oleh penyataan informan bahwasannya kemungkinan pelaksanaan karena posyandu diselenggarakan mulai jam 09.00 hingga 12.00 pada hari kerja.

Dalam teori WHO, dijelaskan bahwa pengetahuan individu dipengaruhi oleh pengalaman seseorang, faktor-faktor di luar orang tersebut seperti lingkungan, baik lingkungan fisik maupun nonfisik dan sosial budaya yang kemudian pengalaman tersebut diketahui, dipersepsikan, diyakini sehingga menimbulkan motivasi, niat untuk bertindak dan akhirnya menjadi perilaku (Soekidjo Notoadmodjo, 2012).

Berdasarkan asumsi peneliti didapatkan bahwa dengan pengetahuan yang baik yang dimiliki ibu balita mengenai posyandu, maka ada kecenderungan berpengaruh terhadap terbentuknya perilaku yaitu ibu balita dapat berpartisipasi aktif ke posyandu. Apabila perilaku tersebut tidak didasari pengetahuan, maka akan sulit dipertahankan kelanggengannya, begitupun sebaliknya jika perilaku didasari oleh pengetahuan, maka perilaku tersebut bersikap langgeng. Ibu balita dengan pengetahuan tinggi pada umumnya memiliki cakupan penimbangan yang baik untuk pemantauan tumbuh kembang balitanya, hal ini disebabkan karena ibu balita mengerti tentang manfaat dari kegiatan Posyandu. Sedangkan ibu balita yang memiliki pengetahuan rendah tidak memiliki cakupan penimbangan balita yang baik, hal ini disebabkan adanya asumsi bahwa kegiatan Posyandu hanya untuk mendapatkan imunisasi sehingga ketika belitanya sudah mendapatkan imuniasi lengkap tidak perlu lagi berkunjung ke Posyandu untuk menimbang balitanya. 
Berdasarkan asumsi peneliti, motivasi ibu dalam pemanfaatan balita merupakan suatu dorongan yang terdapat dalam diri ibu sehingga menimbulkan, mengarahkan, dan mengorganisasikan tingkah lakunya. Hal ini terkait dengan upaya untuk memenuhi kebutuhan yang dirasakan balita yaitu untuk meningkatkan derajat kesehatannya. Seseorang memerlukan dukungan untuk dapat meningkatkan motivasi yang ada pada dirinya sampai motivasi tersebut dapat berpengaruh terhadap sikapnya dalam membawa anaknya ke Posyandu. Motivasi yang tinggi tidak tergantung dari tolak ukur pendidikan seseorang tetapi juga dari dorongan sekitar.

Bagi ibu yang memiliki motivasi tinggi dan cakupan penimbangan balitanya tinggi, hal ini disebabkan karena ibu menganggap membawa anaknya ke Posyandu sebagai sebuah kebutuhan yang harus dipenuhi untuk mengetahui sejah mana pertumbuhan dan perkembangan balitanya. Tetapi ada juga ibu yang memiliki motivasi tinggi tidak berkunjung ke Posyandu, hal ini disebabkan karena masih ada ibu yang beraktifitas diluar rumah sehingga belum bisa membawa balitanya ke Posyandu. Diharapkan peran tenaga kesehatan atau memberikan pelayanan diluar jam kerja dengan mendatangi ibu balita yang tidak berkunjung ke Posyandu.

Menurut asumsi peneliti bahwa masih rendahnya cakupan penimbangan balita ke Posyandu di Puskesmas Kota Padang dikarenakan oleh faktor dukungan keluarga. Oleh karena itu ada hubungan dukungan keluarga dengan cakupan penimbangan balita ke Posyandu. Ibu balita yang mendapatkan dukungan baik dari keluarga pada umumnya masih memiliki cakupan penimbangan balita yang tinggi, hal ini kemungkinan disebabkan karena dukungan keluarga selalu mengingatkan jadwal Posyandu dan memberikan dorongan untuk membawa balitanya ke Posyandu. Sedangkan ibu balita yang memiliki dukungan keluarga kurang baik, tidak memiliki cakupan penimbangan balita yang tinggi, kemungkinan disebabkan karena tidak adanya anggota keluarga yang menggantikan ibu untuk membawa balitanya ke Posyandu ketika ibu bekerja.

Tokoh Masyarakat merupakan bagian dari masyarakat sehingga perilaku keluarga tidak dapat dipisahkan dari perilaku masyarakat di sekitarnya. Menurut (Soekidjo Notoadmodjo, 2012) bahwa tokoh masyarakat adalah jembatan antara sektor kesehatan dengan masyarakat. Jadi, tokoh masyarakat sangat berpengaruh terhadap perilaku seseorang dalam berpartisipasi ke posyandu.

Berdasarkan teori dan beberapa hasil penelitian diatas, peneliti dapat menyimpulkan bahwa, perilaku seseorang dapat mempengaruhi ketidakhadiran ibu dalam kegiatan posyandu. Apabila ibu balita mendapatkan dukungan, namun ia melihat tokoh masyarakat dan ibu balita lainnya tidak ikut serta dalam kegiatan posyandu, maka ia tidak akan memaksakan dirinya untuk berpartisipasi aktif dalam kegiatan posyandu itu sendiri. Hasil penelitian ini didukung oleh pernyataan informan, bahwasannya Posyandu ini adalah miliknya masyarakat maka perlu adanya keikutsertaan dari pemilik wilayah yang dalam hal ini adalah kelurahan, RT/RW dan Tokoh masyarakat untuk memberikan dukungan kepada ibu yang memilki balita agar membawa anaknya ke Posyandu Balita untuk ditimbang.

\section{Analisis Multivariat}

Tabel 3. Analisis Multivariat

\begin{tabular}{lrrr}
\hline Variabel & P-value & $\operatorname{Exp(B)}$ & R.square \\
\hline Pendidikan Ibu & $\mathbf{0 , 0 0 0 1}$ & $\mathbf{0 , 1 7 2}$ & \\
Pekerjaan Ibu & $\mathbf{, 0 0 0 1}$ & $\mathbf{, 1 8 9}$ & $\mathbf{0 , 2 1 6}$ \\
& & & \\
$\begin{array}{l}\text { Dukungan } \\
\text { Keluarga }\end{array}$ & $\mathbf{0 , 0 0 0 1}$ & $\mathbf{0 , 4 0 3}$ & \\
\hline
\end{tabular}

Berdasarkan tabel diatas, variabel yang paling berpengaruh terhadap cakupan penimbangan balita adalah Pendidikan Ibu, pekerjaan ibu dan dukungan keluarga dengan nilai p masing-masing sebesar 0,0001. Berdasarkan hasil uji regeresi logistik didapatkan nilai Exp (B) sebesar 0,216 = 2,16 $\%$ artinya Kuat hubungan dari semua variabel diatas yaitu sebesar $21,6 \%$ semua variabel cukup kuat untuk mempengaruhi cakupan penimbangan balita $(\mathrm{D} / \mathrm{S})$.

Berdasarkan hasil uji statistik regersi logistik didapatkan hasil bahwa variabel yang paling berpengaruh terhadap cakupan penimbangan balita adalah Pendidikan Ibu, pekerjaan ibu dan dukungan keluarga dengan nilai p masing-masing sebesar 0,0001 . Berdasarkan hasil uji regeresi logistik didapatkan nilai Exp (B) sebesar 0,216 = 2,16 $\%$ artinya Kuat hubungan dari semua variabel diatas yaitu sebesar $21,6 \%$ semua variabel 
cukup kuat untuk mempengaruhi cakupan penimbangan balita $(\mathrm{D} / \mathrm{S})$.

\section{Analisa Kualitatif}

Cakupan penimbangan balita di Puskesmas Kota Padang masih rendah dikarenakan banyak faktor yang mempengaruhi diantaranya kerjasama lintas sektor harus diperhatikan yang dalam hal ini adalah kerjasama antara Dinas Kesehatan dan pemilik wilayah, proyeksi jumlah balita dari pemerintah terlalu tinggi, jadwal kegiatan Posyandu yang dijadwal pada saat jam kerja yaitu jam 09.00-12.00 WIB dan wilayah kerja Dinas Kesehatan Kota adalah letaknya di daerah Perkotaan.

Berdasarkan hal tersebut, dapat disimpulkan bahwa kegiatan Posyandu merupakan usaha kegiatan berbasis masyarakat berupa pemberdayaan. Oleh karena itu baik dari Dinas Kesehatan Kota Padang maupun pemilik wilayah dalam hal ini Kelurahan, RT/RW dan tokoh masyarakat harus saling bertintegrasi dalam upaya peningkatan cakupan penimbangan balita, dan jadwal pelaksanaan Posyandu Balita yang dilakukan pada saat jam kerja ibu-ibu mengakibatkan ibu yang memiliki balita tidak bisa membawa balitanya ke Posyandu, hal tersebut bisa disiasati oleh pihak Dinas Kesehatan Kota Padang yang dalam hal ini dilaksanakan oleh Puskesmas melakukan kunjungan rumah ibu yang memiliki balita untuk melakukan program penimbangan balitanya.

Untuk menghindari data proyeksi tentang jumlah balita di Kota Padang yang tinggi, Puskesmas perlu melakukan Mapping data balita yang ada di wilayah kerja Puskesmas masing-masing dengan metode Survei Mawas Diri (SMD). Agar angka cakupan penimbangan balita bisa mencapai target yang ditetapkan oleh pemerintah.

\section{SIMPULAN}

Berdasarkan hasil yang didapatkan, dapat disimpulkan bahwa:

1. Kurang dari separuh $(48,8 \%)$ cakupan penimbangan balita $(\mathrm{D} / \mathrm{S})$ adalah termasuk kategori rendah di Kota Padang tahun 2018

2. Lebih dari separuh $(61,7 \%)$ tingkat pendidikan ibu termasuk kategori rendah di Kota Padang tahun 2018

3. Kurang dari separuh (42\%) ibu adalah termasuk kategori bekerja di Kota Padang Tahun 2018

4. Kurang dari separuh (30,4\%) Tingkat pengetahuan ibu adalah termasuk kategori rendah di Kota Padang tahun 2018

5. Sebagian kecil $(3,1 \%)$ jarak ke Posyandu Balita adalah termasuk kategori jauh di Kota Padang tahun 2018

6. Kurang dari separuh $(41,2 \%)$ Motivasi ibu adalah termasuk kategori rendah di Kota Padang tahun 2018

7. Kurang dari separuh (32,5\%) Dukungan keluarga adalah termasuk kategori kurang baik di Kota Padang tahun 2018

8. Kurang dari separuh $(47,5 \%)$ dukungan tokoh masyarkat adalah termasuk kategori kurang baik di Kota Padang tahun 2018

9. Ada hubungan tingkat pendidikan dengan cakupan penimbangan balita (D/S) di Kota Padang tahun 2018

10. Ada hubungan pekerjaan dengan cakupan penimbangan balita $(\mathrm{D} / \mathrm{S})$ di Kota Padang tahun 2018

11. Ada hubungan tingkat pengetahuan dengan cakupan penimbangan balita (D/S) di Kota Padang tahun 2018

12. Tidak ada hubungan jarak ke Posyandu Balita dengan cakupan penimbangan balita (D/S) di Kota Padang tahun 2018

13. Ada hubungan Motivasi Ibu dengan cakupan penimbangan balita $(\mathrm{D} / \mathrm{S})$ di Kota Padang tahun 2018

14. Ada hubungan Dukungan keluarga dengan cakupan penimbangan balita (D/S) di Kota Padang tahun 2018

15. Tidak ada hubungan dukungan tokoh masyarakat dengan cakupan penimbangan balita (D/S) di Kota Padang tahun 2018

16. Tingkat pendidikan, pekerjaan Ibu dan dukungan keluarga merupakan variabel yang paling berpengaruh terhadap cakupan penimbangan balita ke Posyandu Kota Padang tahun 2018 


\section{UCAPAN TERIMA KASIH}

Pada kesempatan ini penulis mengucapkan terimakasih kepada Pembimbing Bapak Prof.Dr.dr.Nursal Asbiran dan Ibu Sukarsi Rusti,SKM,M.Epid yang telah banyak membantu peneliti untuk perkembangan dari tesis ini. Dan terimakasih juga kepada Ketua STIKes Fort De Kock Bukittinggi dan Ibu Kepala Dinas Kesehatan Kota Padang, Kepala Puskesmas se Kota Padang yang telah memfasilitasi dalam penelitian ini.

\section{DAFTAR PUSTAKA}

A.H Angkat. (2015). Faktor-faktor yang Berhubungan dengan Partisipasi Ibu Balita Menimbang anaknya ke Posyandu di Desa Pananggalan Kecamatan Pananggalan Kota Subulussalam, Medan, Universitas Sumatera Utara. Universitas Sumatera Utara.

Ann, K. (2017). Factors Influencing
Community Participation In Maternal Health Care Project In Kitui County A Research Project Report Submitted In Partial Fulfillment of The Requirement For The Award Of Master Of Arts Degree In Project Planning And Management At The University Of Nairobi.

Jane Ilusa Nyabuti. (2015). Factors Associated With The Continuation Of Growth Monitoring Among Children 10 To 59 Month Old In Nyamira County Kenya.

Kesehatan Kementerian. (2012). Ayo Ke Posyandu. Jakarta.

Padang, K. (2017). Profil Kesehatan Kota Padang.

Soekidjo Notoadmodjo. (2012). Promosi Kesehatan Teori Dan Aplikasi. Jakarta.

Zulkifli. (2003). Posyandu Dan Kader Kesehatan. Pelaksanaan Program Deteksi Dini Tumbuh Kembang Balita Di Posyandu. Digitized By Usu Digital Library, 1-6. 